\title{
Production and efficiency of organic compost generated by millipede activity
}

\author{
Produção e eficiência de composto orgânico gerado pela atividade de gongolos
}

\author{
Luiz Fernando de Sousa Antunes ${ }^{\mathrm{I}}$ Rafael Nogueira Scoriza ${ }^{\mathrm{I}^{*}}$ \\ Dione Galvão da SilvaII Maria Elizabeth Fernandes Correia ${ }^{I I}$
}

\section{ABSTRACT}

The putrefactive activity of organisms such as diplopods in the edaphic macrof auna can be leveraged to promote the transformation of agricultural and urban waste into a lowcost substrate for the production of vegetable seedlings. This research aimed to evaluate: (1) the quantity of Gervais millipedes (Trigoniulus corallinus) needed to produce an acceptable quantity of organic compost; (2) the main physical and chemical characteristics of different compost types; and (3) compost efficiency in the production of lettuce seedlings. The first experiment lasted 90 days and was conducted using 6.5L of Gliricidia, $6.5 \mathrm{~L}$ of Flemingia, 13.5L of grass cuttings, $4.5 \mathrm{~L}$ of cardboard, $4.5 \mathrm{~L}$ of coconut husk, and 4.5L of corncob. Treatments consisting of 0, 0.10, $0.30,0.50$, and $0.90 \mathrm{~L}$ of millipedes were applied. This experiment compared millicompost and vermicompost, using four repetitions. After 23 days, the heights of grown lettuce plants and the weights of the fresh and dry mass of above ground lettuce and of the roots were assessed. A millipede volume of $0.1 \mathrm{~L}$ proved to be sufficient for the production of an acceptable volume of organic compost. However, the addition of greater volumes leads to increased calcium, magnesium, and phosphorous content. Millicompost has similar physicochemical characteristics those of vermicompost, and both are equally efficient as a substrate for the production of lettuce seedlings.

Key words: Diplopoda, substrate, vegetables.

\section{RESUMO}

A atividade decompositora de organismos da macrofauna edáfica, como os diplópodes, pode ser aproveitada para promover a transformação de resíduos agrícolas e urbanos, capaz de produzir um substrato de baixo custo para a produção de mudas de hortaliças. Este trabalho objetivou avaliar: (1) a quantidade de gongolo Trigoniulus corallinus Gervais suficiente para a produção de composto orgânico; (2) suas principais características físicas e químicas; (3) sua eficiência, quando utilizado para a produção de mudas de alface. $O$ primeiro experimento durou 90 dias, utilizando 6,5 litros de gliricídea, 6,5 litros de flemingea, 13,5 litros de aparas de grama, 4,5 litros de papelão, 4,5 litros de casca de coco e 4,5 litros de sabugo de milho. Os volumes de gongolos utilizados como tratamento foram 0, 0,10, 0,30, 0,50 e 0,90 litros. Após 23 dias, foram avaliados os pesos da massa fresca e seca da parte aérea e das raízes e altura. $O$ volume de 0,1 litros de gongolos mostrou-se suficiente para a produção de um volume aceitável de composto orgânico. Entretanto, a adição de maiores volumes proporciona aumento nos teores de cálcio, magnésio e fósforo. O gongocomposto apresenta características físico-química semelhantes ao vermicomposto, ambos igualmente eficientes quando utilizados como substrato para a produção de mudas de alface.

Palavras-chave: diplópodes, substrato, hortaliças.

\section{INTRODUCTION}

Composting is a complex process by which plant and animal waste are converted into stable organic matter, facilitated by a variety of macroorganisms from the saprophage fauna and by microorganisms (AMBARISH \& SRIDHAR, 2013). It is means to mitigate the environmental impact associated with the inadequate disposal of organic waste, since compost has a beneficial effect on crops when used as a fertilizer (KARTHIGEYAN \& ALAGESAN, 2011; DORES-SILVA et al., 2013).

Among the organisms capable of promoting composting, diplopods stand out as one of

\footnotetext{
'Programa de Pós-graduação em Agronomia, Ciência do Solo, Universidade Federal Rural do Rio de Janeiro (UFRRJ), BR 465, km 7, 23890-000, Seropédica, RJ, Brasil. E-mail: rafaelscoriza@gmail.com. "Corresponding author.

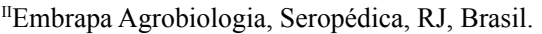


the most active saprophages (THAKUR et al., 2011). They perform important pedogenetic processes, such as nutrient cycling, in the soil as well as being involved in the fragmentation and transformation of organic material (ANILKUMAR et al., 2012) and the composting of plant waste (KANIA \& KLAPEC, 2012). In the perspective of managing and using biota from the soil, a species with potential for this purpose is Trigoniulus corallinus. Known popularly as millipedes, they are distributed across the tropics and can be easily identified in agricultural environments due to their distinctive red color. They belong to the order Spirobolida and the family Pachybolidae; theyare native to Southeast Asia (BIANCHI \& CORREIA, 2007; SHELLEY et al., 2006).

Millipedes transform plant material into fecal pellets that affect important physiochemical properties, specifically by decreasing the carbon/ nitrogen ratio and in the subsequent process of decomposition (KARTHIGEYAN \& ALAGESAN, 2011; THAKUR et al., 2011; ANILKUMAR et al., 2012;). This is important for compost generation, as it provides important nutritional components to the microflora (KANIA \& KLAPEC, 2012).

Farmers can produce and use compost themselves by utilizing plant remains obtained from their property or the surrounding region, which are considered economically important sources of nutrients (SILVEIRA al., 2002; MEDEIROS et al., 2007; ARAÚJO NETO et al., 2009) and play a central role in sustainable agriculture (KARTHIGEYAN \& ALAGESAN, 2011). The search for quality substrates is important owing to the broad use of these substrates in the production of vegetable seedlings (SILVEIRA et al., 2002) since substrates have several advantages, such as the optimization of labor, input, and fertilizers (LOPES et al., 2007), obtaining high-quality seedlings (BRITO et al., 2002) and ensuring the success of other steps in the productive process. In addition, the absence of soil in the substrate facilitates the removal of the seedling with the clod and prevents the occurrence of phytopathogens and seeds from weeds (FILGUEIRA, 2000).

Lettuce is the most cultivated leafy vegetable and an important part of the Brazilian diet (LOPES et al., 2007; MEDEIROS et al., 2007), and it is common to use organic substrates for the production and development of its seedlings (GOMES et al., 2008). This study aimed to assess (1) the amount of Trigoniulus corallinus millipedes sufficient for transforming waste into organic compost; (2) the main physicochemical characteristics of compost; and (3) compost efficiency when used as a substrate for the production of lettuce seedlings.

\section{MATERIALS AND METHODS}

Adults $\boldsymbol{T}$. corallines individuals were manually collected between January and March 2013 from worm culture beds, compost heaps, and recently cut grasses. They were maintained in colonies at the experimental site at the Embrapa Agrobiologia located in Seropédica - RJ, following the recommendations of BIANCHI \& CORREIA (2007).

The determination of the volume of millipedes that was sufficient to carry out composting was conducted using concrete tubes $0.5 \mathrm{~m}$ high and $1 \mathrm{~m}$ in diameter, internally coated with a layer of galvanized steel and covered with a 2-mm screen to prevent the diplopods from escaping. The plant materials used in the composting, at a final volume of $40 \mathrm{~L}$, consisted of $6.5 \mathrm{~L}$ of Gliricidia branches and leaves (Gliricidia sepium (Jacq.) Walp.), 6.5L of Flemingia branches and leaves (Leucaena leucocephala (Lam.) by Wit), 13.5L of cut grass (Brachiaria decumbens Stapf), 4.5L of cardboard, 4.5L of coconut husk (Cocos nucifera L.) and 4.5L of corncob (Zea mays L.). These materials were chopped to $2-\mathrm{cm}$ sized pieces by machine and homogenized.

The experiment was conducted with five treatments: 0 (control), $0.1,0.3,0.5$ and $0.9 \mathrm{~L}$ of diplopods. After 45 days, the material from each tube was again homogenized. After 90 days, the compost from each ring was sieved through a 2-mm mesh screen to separate and measure the volumes of fine and coarse material. This also facilitated the assessment of the reduction in volume in comparison to the initial volume. The volume of the millipedes that survived at the end of the experiment was also assessed. A sample of the fine material was used to evaluate $\mathrm{pH}$ and electric conductivity and nitrogen, calcium, potassium, magnesium, and phosphorous content, according to EMBRAPA (2005).

All of the fine material produced, referred to as millicompost, was mixed and homogenized for use in the production of Regina 2000 (Lactuca sativa L.) lettuce seedlings. Seedlings produced using this treatment were compared to seedlings produced in compost supplied by the Embrapa Agrobiologia experimental field, which contained $83 \%$ vermicompost, $15 \%$ fine plant charcoal and $2 \%$ Caster oil plant paste. Both were physically characterized in order to determine the apparent density, particle density, water retention capacity, macroporosity, microporosity, and total porosity, according to SILVA (1998) and MAPA (2007). 
The delineation was entirely randomized in four repetitions. Seeding was carried out in trays using two pelleted seeds per cell. Thinning took place after nine days, and left only one plant per cell. The experiment was terminated after 23 days, and 16 plants were collected per tray from the fifth line in the larger direction, discarding the first two cells from each end. The assessment of the seedlings was based on the determination of the fresh mass of the plant above the ground and roots, the dry mass of the aboveground plant and roots, the number of true leaves and the height of the plants (from the root insertion point to the peak of the foliage). To determine dry mass, the aboveground plant and the roots were stored in paper bags and kept in a forced air circulation greenhouse at $65^{\circ} \mathrm{C}$ until they reached a constant weight.

For the data analysis, the homogeneity of the error variances was assessed using the Cochran Test and normality using the Lilliefors Test. The parametric data were subjected to variance analysis using Tukey's test $(\mathrm{P} \leq 0.05)$.

\section{RESULTS AND DISCUSSION}

The activity of the Trigoniulus corallinus individuals was efficient in promoting the digestion and fragmentation of the plant materials. Compared to the control, there was a significant increase in the volume of fine material, which is compost formed by fecal pellets (THAKUR et al., 2011) and fragmented parts $(\leq 2 \mathrm{~mm})$.

The presence of millipedes also promoted an approximate $60 \%$ reduction in the initial volume compared to the control (Table 1). The insertion of grass may have increased this process since it has a low $\mathrm{C} / \mathrm{N}$ ratio $(29: 1)$ and is an organic matter that is more susceptible to microbiological degradation (GODOY et al., 2009).

Contrary to what was expected, the different volumes of millipedes assessed in this study did not significantly reduce the initial volume and fine material produced. This indicates that the activity of individual organisms did not promote a synergistic effect in the composting of the plant material, which could be related to the low survival of the inserted organisms, especially in treatments using larger volumes of millipedes (Table 1). This low survival was also observed (although it was not quantified) in the colony in which the millipedes were maintained. Thus, a volume of $0.1 \mathrm{~L}$ was considered sufficient, representing an average production of $41.4 \%(6.5 \mathrm{~L})$ of the millicompost in this study; this production efficiency is comparable to that of vermicompost, for which the expected production is between $40 \%$ and $60 \%$ (GODOY et al., 2009).

In the treatment without millipedes, the volume of fine material generated is attributed to decomposition promoted by opportunistic groups from the macrofauna that were occasionally observed in the compost, such as Isopoda and Blattodea. These organisms could either have come from material collected in the field, or they may have been present in the concrete rings during the experiment.

The addition of larger volumes of millipedes resulted in changes in the chemical characteristics of the compost and an increase in the content of macronutrients such as calcium, magnesium, and phosphorous (Table 1). The increased content of these nutrients in the substrate produced by diplopods was observed by KARTHIGEYAN \& ALAGESAN (2011) and AMBARISH \& SRIDHAR (2013), who also reported an increase in the levels of organic

Table 1 - Characteristics of the compost produced by different volumes of Trigoniulus corallinus after 90 days under greenhouse conditions.

\begin{tabular}{|c|c|c|c|c|c|}
\hline & $0 \mathrm{~L}$ & $0.1 \mathrm{~L}$ & $0.3 \mathrm{~L}$ & $0.5 \mathrm{~L}$ & $0.9 \mathrm{~L}$ \\
\hline Coarse material (\%) & $85.4 \mathrm{a}$ & $58.6 \mathrm{~b}$ & $54.0 \mathrm{~b}$ & $58.2 \mathrm{~b}$ & $51.8 \mathrm{~b}$ \\
\hline Fine material $(\%)$ & $14.6 \mathrm{~b}$ & $41.4 \mathrm{a}$ & $46.0 \mathrm{a}$ & $41.8 \mathrm{a}$ & $48.2 \mathrm{a}$ \\
\hline Volume reduction (\%) & $47.8 \mathrm{~b}$ & $61.3 \mathrm{a}$ & $61.8 \mathrm{a}$ & $63.0 \mathrm{a}$ & $59.0 \mathrm{a}$ \\
\hline Survival (\%) & & $27.0 \mathrm{a}$ & $8.7 \mathrm{~b}$ & $4.8 \mathrm{~b}$ & $5.0 \mathrm{~b}$ \\
\hline Nitrogen $(\%)$ & $2.2 \mathrm{a}$ & $2.0 \mathrm{a}$ & $2.2 \mathrm{a}$ & $2.1 \mathrm{a}$ & $2.1 \mathrm{a}$ \\
\hline Calcium $\left(\mathrm{g} \mathrm{kg}^{-1}\right)$ & $12.7 \mathrm{c}$ & $17.1 \mathrm{bc}$ & $26.4 \mathrm{bc}$ & $30.4 \mathrm{~b}$ & $51.1 \mathrm{a}$ \\
\hline Potassium $\left(\mathrm{g} \mathrm{kg}^{-1}\right)$ & $12.1 \mathrm{a}$ & $12.3 \mathrm{a}$ & $11.3 \mathrm{a}$ & $11.4 \mathrm{a}$ & $10.2 \mathrm{a}$ \\
\hline Magnesium $\left(\mathrm{g} \mathrm{kg}^{-1}\right)$ & $4.0 \mathrm{~b}$ & $4.0 \mathrm{~b}$ & $4.6 \mathrm{~b}$ & $4.7 \mathrm{~b}$ & $6.9 \mathrm{a}$ \\
\hline Phosphorous $\left(\mathrm{g} \mathrm{kg}^{-1}\right)$ & $2.0 \mathrm{~d}$ & $2.3 \mathrm{~cd}$ & $3.3 \mathrm{bc}$ & $3.7 \mathrm{~b}$ & $6.0 \mathrm{a}$ \\
\hline
\end{tabular}

Similar letters on a line indicate that there was no statistical difference according to Tukey's test at $5 \%$.

Ciência Rural, v.46, n.5, mai, 2016. 
carbon, nitrogen, carbohydrates, and lipids. In another type of compost generated by earthworm activity, an increase in the levels of total nitrogen and phosphorous was also observed after composting plant waste with manure, thus increasing the fertilizing capacity of the final compost (DORES-SILVA et al., 2013).

One explanation for the increase in the nutrient content is that a larger volume of individuals represented greater activity from the microorganisms present in the intestine of the millipedes, thus mobilizing the nutrients trapped in the plant material and eliminating a portion in the feces. The pellets also contained a rich array of microorganisms whose tissues have high nutritional quality (SWIFT et al., 1979; ANILKUMAR et al., 2012; AMBARISH \& SRIDHAR, 2013). Another factor that should be considered is the low survival of millipedes (Table 1), and the incorporation of nutrients found in their bodies to the compost. According to TEUBEN \& VERHOEF (1992), the diplopod biomass is a very rich source of nutrients that has 5 times more potassium, 20 times more calcium, 3 times more magnesium, 17 times more phosphorous and 4 times more nitrogen than the original plant material.

The use of millicompost as a substrate allows for the production of lettuce seedlings with characteristics that are similar to those produced using vermicompost, which is commonly used by farmers (Table 2). However, lettuce production is always coupled with animal manure, the supply of which could be limited if there are no properties that carry out livestock activities in the region.

The two types of compost were statistically similar in terms of all measured characteristics (e.g., dry mass, height, and number of leaves). Lettuce seedlings with characteristics similar to those of the lettuce produced in this study (Table 2) were produced by GOMES et al. (2008) in a substrate with a mixture of earthworm humus $(70 \%)$, rice husk $(30 \%)$, and phosphate, after 21 days, with fresh and dry mass from the aerial part at $0.37 \mathrm{~g}$ and $0.03 \mathrm{~g}$, respectively.

The efficiency of both composts was compared by ANILKUMAR et al. (2012) for the production of Caspicum annuum, and this comparison confirmed that better results are obtained from millipedeproduced compost. The similarity in the production of lettuce seedlings by both organic composts could be the result of similarities of their main physical and chemical characteristics (Table 2). The proportion of water retention is related to the microporosity of the compost, as suggested by PRIMO et al. (2011). According to the authors, this is owing to a reduction in the size of the particles in the raw material. The $\mathrm{pH}$ measured is considered ideal for the successful development of
Table 2 - Characteristics of the lettuce seedlings, the clod, and the physical and chemical analysis of the organic substrates used for producing lettuce seedlings.

\begin{tabular}{lll}
\hline & Millicompost & Vermicompost \\
\hline $\begin{array}{l}\text { Fresh mass of the } \\
\text { aboveground plant (g) }\end{array}$ & $0.62 \mathrm{a}$ & $0.57 \mathrm{a}$ \\
$\begin{array}{l}\text { Fresh mass of the roots (g) } \\
\text { Dry mass of the }\end{array}$ & $0.10 \mathrm{a}$ & $0.11 \mathrm{a}$ \\
aboveground plant (g) & $0.02 \mathrm{a}$ & $0.02 \mathrm{a}$ \\
Dry mass of the roots (g) & $0.004 \mathrm{a}$ & $0.003 \mathrm{a}$ \\
Number of real leaves & $6.81 \mathrm{a}$ & $7.14 \mathrm{a}$ \\
$\begin{array}{l}\text { Average height of the plants } \\
\text { (cm) }\end{array}$ & $5.48 \mathrm{a}$ & $5.15 \mathrm{a}$ \\
$\begin{array}{l}\text { Apparent density (kg m } \\
\left.\text { Particle density (kg m }{ }^{-3}\right)\end{array}$ & 270 & 350 \\
Total porosity (\%) & 750 & 1710 \\
Microporosity (\%) & 64.5 & 79.3 \\
Macroporosity (\%) & 48.1 & 59.9 \\
Water retention (\%) & 16.4 & 19.4 \\
pH & 48 & 59.8 \\
$\begin{array}{l}\text { Electric conductivity } \\
\text { (mScm }\end{array}$ & 5.8 & 6.5 \\
Available/total nitrogen $(\%)$ & 4 & 0.2 \\
\hline
\end{tabular}

Millicompost generated by the activity of Trigoniulus corallinus, over 90 days, on agricultural and urban plant remains. Vermicompost supplied by the Embrapa Agrobiologia experimental field, containing $83 \%$ vermicompost, $15 \%$ fine plant charcoal and $2 \%$ Caster oil plant paste.

lettuce seedlings, according to MENEZES JÚNIOR et al (2000), as it is near 6.0 in both composts. This characteristic is a result of the use of organic matter in composition of both types of compost, which also contributes to permeability, aggregation of mineral particles, and acid correction (MIRANDA et al., 1998).

There is a large difference in the density of particles between composts - vermicompost has a higher density, possibly caused by the presence of earthworm coprolites (ARAÚJO NETO et al., 2009). This characteristic is less prevalent in millicompost. This is of relevanceto the transport of the trays where the seedlings are produced (MIRANDA et al., 1998).

Further studies should be conducted to assess the quality of compost produced from other raw materials, in addition to developing maintenance techniques that permit greater survival and reproduction of the composting organisms, thereby facilitating the management of these organisms.

\section{CONCLUSION}

The Trigoniulus corallinus millipede decomposes agricultural and urban plant waste. 
Nutritional enrichment with calcium, magnesium, and phosphorus, and the physicochemical characteristics of the compost generated by these organisms, make them efficient as a substrate for the production of lettuce seedlings.

\section{REFERENCES}

AMBARISH, C.N.; SRIDHAR, K.R. Production and quality of pill-millipede manure: a microcosm study. Agricultural Research, v.2, n.3, p.258-264, Ago. 2013. Available from: <http:// link.springer.com/article/10.1007/s40003-013-0075-5>. Accessed: May 17, 2015. doi: 10.1007/s40003-013-0075-5.

ANILKUMAR, C. et al. Evaluation of millicompost versus vermicompost. Current Science, v.103, n.2, p.140-143, Jul. 2012. Available from: <http:/www.environmentportal.in/files/file/ millicompost.pdf $>$. Accessed: May 17, 2015.

ARAÚJO NETO, S.E. et al. Organic production of seedlings of sweet pepper with different substrates. Ciência Rural, v.39, n.5, p.1408-1413, Ago. 2009. Available from: <http://www.scielo.br/ pdf/cr/v39n5/a194cr397>. Accessed: May 17, 2015. doi: 10.1590/ S0103-84782009005000099.

BIANCHI, M.O.; CORREIA, M.E.F. Mensuração do consumo de material vegetal depositado sobre o solo por diplópodes. Seropédica: Embrapa Agrobiologia, 2007. 4p. Circular Técnica, 20.

BRITO, T.D. et al. Performance of substrates for lettuce seedling production in organic agriculture. Horticultura Brasileira, v.20, n.2, supl.2, Jul. 2002. Available from: <http://www.abhorticultura. com.br/biblioteca/arquivos/Download/Biblioteca/42_033.pdf $>$. Accessed: May 17, 2015.

DORES-SILVA, P.R. et al. The organic waste stabilization process: composting versus vermicomposting. Química Nova, v.36, n.5, p.640-645, 2013. Available from: <http://www.scielo.br/pdf/qn/ v36n5/05.pdf >. Accessed: May 17, 2015.

EMBRAPA. Manual de laboratórios: solo, água, nutrição, animal e alimentos. São Carlos: Embrapa Pecuária Sudeste, 2005. 334p.

FILGUEIRA, F.A.R. Novo manual de olericultura. Viçosa: UFV, 2000. 402p.

GODOY, J.R.R. et al. Vermicomposting of biosolid from sanitary sewage by Eisenia foetida (Savigny, 1826). Revista Ceres, v.56, n.5, p.648-653, Sept./Oct. 2009. Available from: <http:// www.ceres.ufv.br/ojs/index.php/ceres/article/view/3479/1378>. Accessed: May 17, 2015.

GOMES, L.A.A. et al. Production of lettuce seedling using alternative substrates and fertilizer. Horticultura Brasileira, v.26, n.3, p.359-363, Jul./Sept. 2008. Available from: <http://www. horticulturabrasileira.com.br/images/stories/26_3/200826312.pdf>. Accessed: May 17, 2015. doi: 10.1590/S0102-05362008000300013.

KANIA, G.; KLAPEC, T. Seasonal activity of millipedes (Diplopoda) - their economic and medical significance. Annals of Agricultural and Environmental Medicine, v.19, n.4, p.646 650, 2012. Available from: <http://yadda.icm.edu.pl/yadda/ element/bwmeta1.element.agro-7d3dfa05-3d77-4b0a-a050495cb4087ae3/c/fulltext415.pdf>. Accessed: May 17, 2015.
KARTHIGEYAN, M.; ALAGESAN, P. Millipede composting: a novel method for organic waste recycling. Recent Research in Science and Technology, v.3, n.9, p.62-67, 2011. Available from: $<$ http://recent-science. com/index.php/rrst/article/viewArticle/8591>. Accessed: May 17, 2015.

LOPES, J.L.W. et al. Growth of lettuce seedling in different substrates. Biotemas, v.20, n.4, p.19-25, Dec. 2007. Available from: <https://periodicos.ufsc.br/index.php/biotemas/article/ view/20600/18789>. Accessed: May 17, 2015.

MEDEIROS, D.C. et al. Production of lettuce plantlets using biofertilizer and substrates. Horticultura Brasileira, v.25, n.3, p.433-436, Jul./Sept. 2007. Available from: $<\mathrm{http} / / \mathrm{www}$. scielo.br/pdf/hb/v25n3/a21v25n3>. Accessed: May 17, 2015. doi: 10.1590/S0102-05362007000300021.

MENEZES JÚNIOR, F.O.G. et al. Characterization and performance of diferente for lettuce plug-type transplants production under protected environment. Horticultura Brasileira, v.18, n.3, p.164-170, Nov. 2000. Available from: <http://www. scielo.br/pdf/hb/v18n3/v18n3a04>.Accessed: May 17, 2015. doi: 10.1590/S0102-05362000000300004.

MIRANDA, S. C. et al. Avaliação de substratos alternativos para produção de mudas de alface em bandejas. Seropédica: Embrapa Agrobiologia, 1998. 6p. Comunicado Técnico, 24.

PRIMO, D.C. et al. Rational management of tobacco (Nicotiana tabacum L.) crop residues to obtain organic compost. Semina: Ciências Agrárias, v.32, n.4, p.1275-1286, Oct./Dec. 2011. Available from: <http://www.uel.br/revistas/uel/index.php/ semagrarias/article/view/4861/8892>. Accessed: May 17, 2015. doi: $10.5433 / 1679-0359.2011 \mathrm{v} 32 \mathrm{n} 4 \mathrm{p} 1275$.

SHELLEY, R.M. et al. Introduction of the millipede, Trigoniulus corallinus (Gervais, 1847) (Spirobolida: Trigoniulidae), in Florida, U.S.A. Entomological News, v.117, n.2, p.239-241, May, 2006. Available from: <http://www.bioone.org/doi/full/10.3157/0013-872X\%282006\% 29117\%5B239\%3AIOTMTC\%5D2.0.CO\%3B2>. Accessed: May 17, 2015. doi: 10.3157/0013-872X(2006)117[239:IOTMTC]2.0.CO;2.

SILVA, M.R. Caracterização morfológica, fisiológica e nutricional de mudas de Eucalyptus grandis Hill ex Maiden submetidas a diferentes níveis de estresse hídrico durante a fase de rustificação. 1998. 105f. Dissertação (Mestrado em Silvicultura) - Curso de Pós-graduação em Engenharia Florestal, Universidade Federal do Paraná, PR.

SILVEIRA, E.B. et al. Tomato seedling production using substrates with coconut fiber and rock waste. Horticultura Brasileira, v.20, n.2, p.211-216, Oct./Dec. 2002. Available from: <http://www. scielo.br/pdf/hb/v26n4/v26n4a15.pdf>. Accessed: May 17, 2015. doi: 10.1590/S0102-05362008000400015.

SWIFT, M.J. et al. Decomposition in terrestrial ecosystems. Oxford: Blackwell, 1979. 2v.

TEUBEN, A; VERHOEF, H.A. Direct contribution by soil arthropods to nutrient availability through body and fecal nutrient content. Biology and Fertility of Soils, v.14, p.71-75, Oct. 1992. Available from: <http://link.springer.com/article/10.1007/ BF00336253>. Accessed: May 17, 2015. doi: 10.1007/BF00336253.

THAKUR, P.C. et al. Comparative study of characteristics of biocompost produced by millipedes and earthworms. Advances in Applied Science Research, v.2, n.3, p.94-98, 2011. Available from: $<$ http://pelagiaresearchlibrary.com/advances-in-applied-science/ vol2-iss3/AASR-2011-2-3-94-98.pdf>. Accessed: May 17, 2015. 